\title{
Manure Fertilization Gives High-Quality Earthworm Coprolites with Positive Effects on Plant Growth and N Metabolism
}

\author{
Michela Schiavon ${ }^{1}$, Andrea Ertani ${ }^{1, *} \mathbb{C}$, Ornella Francioso ${ }^{2}\left(\mathbb{D}\right.$ and Serenella Nardi ${ }^{1}(\mathbb{C}$ \\ 1 Department of Agronomy, Food, Natural Resources, Animal and Environment, Agripolis-Viale \\ dell’Università, 16, 35020 Legnaro (Padova), Italy; michela.schiavon@unipd.it (M.S.); \\ serenella.nardi@unipd.it (S.N.) \\ 2 Department of Agricultural and Food Sciences, University of Bologna, Alma Mater Studiorum, Viale Fanin \\ 40, 40127 Bologna, Italy; ornella.francioso@unibo.it \\ * Correspondence: andrea.ertani@unipd.it
}

Received: 10 September 2019; Accepted: 17 October 2019; Published: 19 October 2019

check for updates

\begin{abstract}
Humic substances (HS) are important soil components playing pivotal roles in guaranteeing long-term soil fertility. In this study, the chemical and biological properties of HS extracted from earthworm coprolites collected in soils subjected to different fertilization inputs (no fertilization, NF; fertilization with farmyard manure, FM; mineral input, M; mixed inputs, FMM, half farmyard manure plus half mineral input) were investigated. Results indicated a relationship between fertilization input and composition, molecular complexity and apparent molecular weight distribution of HS produced by earthworms. Coprolites from FM and FMM soils were the most enriched in organic carbon (OC), and HS from coprolites of FM soil were the highest in humic carbon (HC). Also, soil amendment with manure increased carboxylate and aromatic groups in HS, and the fraction with a high degree of polycondensation, thus indicating a positive impact of manure on plant residues' degradation processes. These HS were the only to display hormone-like activity, which likely accounted for their most pronounced positive effects on plant growth and metabolism, including accumulation of chlorophylls, mineral nutrition, and activity of nitrogen assimilation enzymes, in oat (Avena sativa L.) plants growing in a soil-less system. We conclude that manure input favored the turnover of OC towards the humification process that led to the production of high-quality coprolites and HS with superior biological activity, and suggests that $\mathrm{OC}$ in coprolites and $\mathrm{HC}$ in HS from earthworms might be used as reliable indicators of soil fertility.
\end{abstract}

Keywords: earthworm coprolites; humic substances; FT-IR; auxin and gibberellic-like activity; nitrogen assimilation

\section{Introduction}

Earthworms are regarded as key biological agents in the transformation of organic matter and waste, and are considered as ecosystem engineers due to their capacity to influence soil chemistry and plant communities [1]. Indeed, earthworms exert beneficial physical, biological, and chemical actions on soils, and increase plant growth and yields in both natural and managed environments [2-4]. These positive effects have been ascribed to the improvement of soil mineral particles aggregation, greater accessibility of oxygen and water percolation [5], higher availability of mineral nutrients to plants [6], and promotion of microbial populations that produce biologically active metabolites functioning as plant growth regulators [7]. Earthworms are also able to quickly transform organic substances of different origin into humus-like compounds characterized by high biological activity [8]. Specifically, 
they accelerate the humification process by grinding and mixing mineral and organic materials with substances occurring in their gut, and by modifying the composition of microbial populations.

In recent years, earthworms have been used for the breakdown of organic substances in sewage sludges, animal and industrial wastes, and crop residues in order to obtain vermicompost $[9,10]$. The production of vermicompost is a process that also occurs in nature and several studies have been performed to evaluate its nutritional and ecological importance. For example, the pedological process of melanization consisting in the darkening of mineral soils, derives from the deposition of earthworm coprolites on topsoil and their mixture with the humified layers. Some authors in the past tried to quantify the amount of soil casts produced by earthworms, like Darwin [11], who reported values within 18.7-43.5 $\mathrm{t} \mathrm{ha}^{-1} \mathrm{y}^{-1}$, and Evans [12], who stated that $68 \mathrm{t} \mathrm{ha}^{-1} \mathrm{y}^{-1}$ could be cast by earthworms in a 300-year-old pasture.

Earthworm coprolites contain a great quantity of humic substances (HS) that display a plethora of bioactive effects when applied to plants [7,8,13-16]. HS structure has been long under debate, and three main theories have been proposed so far [17-21]. According to Swift [19], HS possess a macromolecular structure that assumes random coil conformations in solution, while Piccolo [17] and Sutton and Sposito [18] suggest that HS consist of relatively small heterogenous organic molecules (sugars, fatty acids, polypeptides, aliphatic chains, and aromatic rings) held by intermolecular hydrophobic interactions and hydrogen bonds. Another theory states that HS behave in solution as micelles or "pseudo micellar" structures [21]. Also, some authors highlighted the issue that HS might be artifacts forming during the alkaline extraction procedure [22], but this theory has been recently contested [23].

Although the existence of these different viewpoints on HS molecular structure, some of their components are critical in the establishment of biotic relationships in the rhizosphere and can interact with plant cell receptors, while triggering plant physiological responses through mechanisms that, so far, are not yet completely elucidated [22].

Humic acids (HA) are HS constituents produced via associations of hydrophobic compounds, such as polymethylene chains, fatty acids, phenolics and steroids, which are stabilized by hydrophobic forces at neutral $\mathrm{pH}$ [17]. HA isolated from earthworms' coprolites in particular, have been reported to stimulate root growth and plant defense systems against stress [24]. However, their bioactivity is a very complex and sometimes controversial issue. Some effects of HS or their constituents HA in plants are related to their hormone-like activities (auxin, gibberellin, and/or cytokine-like substances), and capacity to stimulate plant plasma membrane proton pumps $\left(\mathrm{H}^{+}\right.$-ATPase), consequently promoting root growth via increased nutrient uptake, cell wall modification and cell division [25-29]. Bioactivity of HA is also related to their structure [10]. Muscolo et al. [30] in particular, evidenced the effectiveness of aliphatic- and carboxylic-C groups of HA in interacting with cellular membranes of carrot cell cultures, while Canellas et al. [31] established a relationship between the HA bioactivity and hydrophobicity.

In agroecosystems, the activity of earthworms strongly depends on management practices, such as tillage [32], fertilization [33], use of organic inputs [34,35], residues handling [36] and cropping systems [37]. Such practices may have an effect on the quality of HS contained in earthworm coprolites, with important agronomic implications. Indeed, owing to the morphological, physiological and biochemical effects that HS can exert in plants, soluble HS are increasingly being used as biostimulants or plant growth promoters in agriculture, and their chemical and biological properties are mainly responsible for their efficiency in this respect $[16,38]$.

Therefore, in the present study we investigated the long-term effect of manure and mineral fertilization on the spectroscopic, chemical and biological features of HS extracted from earthworm coprolites. To this aim, the coprolites were collected in soils subjected to farmyard manure, mineral, mixed inputs or no fertilization, and the content, quality and evolution of soil organic matter (SOM) was evaluated. The biological effects of the different HS on growth and $\mathrm{N}$ metabolism of oat (Avena sativa L.) plants were also assayed. 


\section{Results}

\subsection{Chemical Composition and Apparent Molecular Weight of HS}

The analysis performed on earthworm coprolites evidenced their alkaline pH (Table 1), with values ranging from 8.20 if they were obtained from non-fertilized soil (NF), to 8.31 when they were collected from the soil subjected to mineral fertilization (M). The alkalinity of soil is generally favorable to earthworm replication and development. Organic carbon (OC) and nitrogen (N) contents (Table 1) were considerably higher in coprolites found in fertilized soils compared to those derived from the unamended (NF) soil. In particular, coprolites collected from FM and FMM soils led to an enrichment in OC by $1.59 \%$ and $1.51 \%$, respectively, and in $\mathrm{N}$ by $0.16 \%$ and $0.18 \%$ respectively. With respect to $\mathrm{OC}$ and $\mathrm{N}$ contents measured in coprolites from $\mathrm{M}$ soil, values were slightly lower than in coprolites picked in the FM and FMM soils (1.33\% and $0.15 \%$, respectively). The ratio C/N (Table 1) did not show significant variation among coprolite samples and ranged from 8.39 (FMM) to 10.15 (NF). The organic matter (OM) content, followed the same trend as organic carbon (Table 1). The amount of humic carbon (HC) measured in HS from earthworm coprolites was higher in fertilized soils than in NF. In particular, HS from coprolites collected in FM soil hold the highest HC value (0.53\%) (Table 1).

Table 1. Values of $\mathrm{pH}$, organic carbon $(\mathrm{OC})$, organic matter $(\mathrm{OM})$, nitrogen $(\mathrm{N})$ and $\mathrm{C} / \mathrm{N}$ of earthworm coprolites, and humic carbon (HC) of humic substances extracted from earthworm coprolites collected in soil plots fertilized with no inputs (NF), manure (FM), mineral fertilizers (M) and with manure plus mineral fertilizers (FMM). Data represent the means of three measurements. Values in the same row following the same letter are not statistically different at $p<0.05$ according to Student-Newman-Keuls test.

\begin{tabular}{ccccccccc}
\hline Parameter & \multicolumn{2}{c}{ NF } & \multicolumn{2}{c}{ FM } & \multicolumn{2}{c}{ M } & \multicolumn{2}{c}{ FMM } \\
\hline $\mathbf{p H}$ & 8.20 & $\pm 1.10 \mathrm{a}$ & 8.25 & $\pm 1.02 \mathrm{a}$ & 8.31 & $\pm 2.12 \mathrm{a}$ & 8.18 & $\pm 1.88 \mathrm{a}$ \\
$\mathbf{O C} \%$ & 0.75 & $\pm 0.03 \mathrm{c}$ & 1.59 & $\pm 0.06 \mathrm{a}$ & 1.33 & $\pm 0.05 \mathrm{~b}$ & 1.51 & $\pm 0.10 \mathrm{a}$ \\
$\mathbf{O M} \%$ & 1.29 & $\pm 0.06 \mathrm{c}$ & 2.73 & $\pm 0.04 \mathrm{a}$ & 2.28 & $\pm 0.06 \mathrm{~b}$ & 2.60 & $\pm 0.09 \mathrm{a}$ \\
$\mathbf{N} \%$ & 0.07 & $\pm 0.01 \mathrm{~b}$ & 0.16 & $\pm 0.02 \mathrm{a}$ & 0.15 & $\pm 0.04 \mathrm{a}$ & 0.18 & $\pm 0.02 \mathrm{a}$ \\
$\mathbf{C} / \mathbf{N}$ & 10.15 & $\pm 1.11 \mathrm{a}$ & 9.94 & $\pm 1.04 \mathrm{~b}$ & 8.86 & $\pm 1.15 \mathrm{c}$ & 9.43 & $\pm 1.28 \mathrm{c}$ \\
\hline $\mathbf{H C} \%$ & 0.15 & $\pm 0.02 \mathrm{~d}$ & 0.53 & $\pm 0.02 \mathrm{a}$ & 0.23 & $\pm 0.03 \mathrm{c}$ & 0.33 & $\pm 0.02 \mathrm{~b}$ \\
\hline
\end{tabular}

The percent amount of the HS fraction FI $(>100 \mathrm{kDa})$ varied depending on the fertilization treatment (Figure 1). The manure amendment led to a higher percentage (38.4\%) of FI compared to the other treatments. In all HS, the majority of molecular weight distribution was always in the intermediate fraction (FII). The percent amount of this fraction did not significantly differ between HS from coprolites deriving from fertilized and non-fertilized soils, with the exception of HS from coprolites picked in FM soil. In this case, the value of FII percentage was indeed lower, although not significant compared to FMM. The lowest fraction (FIII), which is typical of compounds that have not been yet subjected to the polycondensation process, was more abundant in HS from coprolites of NF soil. No statistical differences in FIII percentages were observed among HS from coprolites collected in fertilized soils.

\subsection{Spectroscopic Characterization of $H S$}

The FT-IR spectra of HS from coprolites were investigated more in detail in the region from 2000 to $600 \mathrm{~cm}^{-1}$ (Figure 2). In general, the spectra showed a similar band pattern, but the relative intensity of main peaks changed in relation to different treatments.

All spectra were characterized by a shoulder at $1711 \mathrm{~cm}^{-1}$ due to $\mathrm{C}=\mathrm{O}$ stretching of $\mathrm{COOH}$ and other carbonyl groups. The region between $1650-1600 \mathrm{~cm}^{-1}$ is usually assigned to different group vibrations including aromatic $\mathrm{C}=\mathrm{C}, \mathrm{C}=\mathrm{O}$ stretching of amide I groups, quinonic $\mathrm{C}=\mathrm{O}$, and/or $\mathrm{C}=\mathrm{O}$ of H-bonded conjugated ketones $[39,40]$. The band at around $1539 \mathrm{~cm}^{-1}$ is preferentially ascribed to 
stretching of amide II group [41]. The presence of the band at $1512 \mathrm{~cm}^{-1}$ was due to $C=C$ stretching vibrations of aromatic ring in lignin [40,42]. The region from 1460 to1450 $\mathrm{cm}^{-1}$ was assigned to C-H deformations and aromatic ring vibrations. The region from 1420 to $1390 \mathrm{~cm}^{-1}$ was due to $\mathrm{O}-\mathrm{H}$ deformation, $\mathrm{C}-\mathrm{OH}$ stretching of phenols, and $\mathrm{C}-\mathrm{H}$ deformation of $\mathrm{CH}_{2}$ and $\mathrm{CH}_{3}$ groups. The region from 1378 to $1330 \mathrm{~cm}^{-1}$ might be attributed to aromatic primary and secondary amines. A broad band centered at around $1216 \mathrm{~cm}^{-1}$ was assigned to C-O stretching and O-H deformation of carboxyl and C-O stretching of aryl ethers. A strong band from 1120 to $980 \mathrm{~cm}^{-1}$ with a sharp peak centered near $1028 \mathrm{~cm}^{-1}$ was attributed to C-O stretching of polysaccharides $[40,41]$.

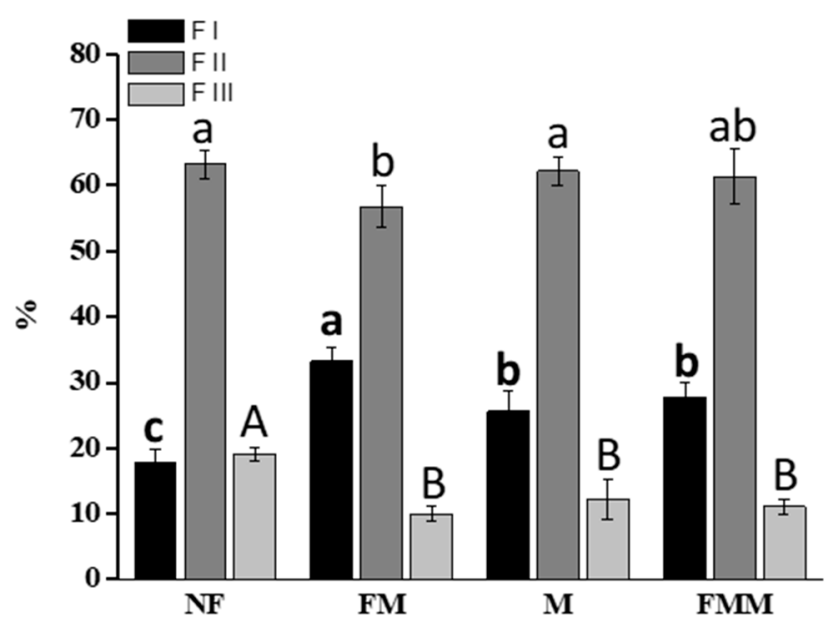

Figure 1. Apparent molecular weight of humic fractions extracted from earthworm coprolites collected in soils fertilized with no inputs (NF), or with manure (FM), mineral fertilizers (M) and with manure plus mineral fertilizers (FMM). FI $>100.000$ kDa; FII 10.000-100.000 kDa; FIII < 10.000 kDa. Data represent the means of three measurements. Values above bars following the same letter are not statistically different at $p<0.05$ according to Student-Newman-Keuls test. Comparisons were carried out within values of the same HS fraction.

The spectrum of HS from coprolites obtained from the soil amended with mineral fertilizers (M) (Figure 2) did not differ from that depicted for HS extracted from coprolites harvested in the NF soil. More variations were observed when HS were derived from coprolites picked in soils amended with manure (FM, FMM). The spectrum of HS from coprolites collected in FM soil displayed an increase in carboxylate groups, as indicated by the appearance of a new shoulder at $1594 \mathrm{~cm}^{-1}$ (COO- asymmetric stretch) and by the enhancement of the relative intensity of the bands at 1417 (COO- symmetric stretch) and $1211 \mathrm{~cm}^{-1}$ (C-OH stretch) [40,42]. Moreover, amide II group vibration at $1538 \mathrm{~cm}^{-1}$ decreased compared to HS coprolites from NF and M soils. The enhancement in aromatic moieties of lignin derivative $\left(1512 \mathrm{~cm}^{-1}\right)$ might be ascribed to a positive impact of manure on the degradation process of plant residues $[43,44]$. The spectrum of HS coprolites from FMM led to a slight increase of the band assigned to vibration of amide II $\left(1539 \mathrm{~cm}^{-1}\right)$ compared to other treatments.

The mineral input added to the manure seemed to preserve the organic $\mathrm{N}$ by a mineralization process. This was also supported by $\mathrm{N}$ content (Table 1). In brief, the soil amended with manure (FM) led to more pronounced enrichment of HS obtained from coprolites in aromatic and carboxylic groups compared to other fertilization treatments.

\subsection{Hormone-like Activity of HS}

In the current study, IAA concentrations inhibited the root elongation of watercress according to a negative dose-dependent response (Figure 3). This trend was in line with a dose-dependent slight reduction of watercress root length evidenced when HS from coprolites deriving from FM soil were applied. In all other cases, inhibition of watercress root elongation was not significantly 
dose-responsive. GA concentrations in the growth media induced the increase in elongation of lettuce shoots according to a positive dose-dependent relationship [45] (Figure 4). A similar trend was only observed for HS of coprolites deriving from FM soil.

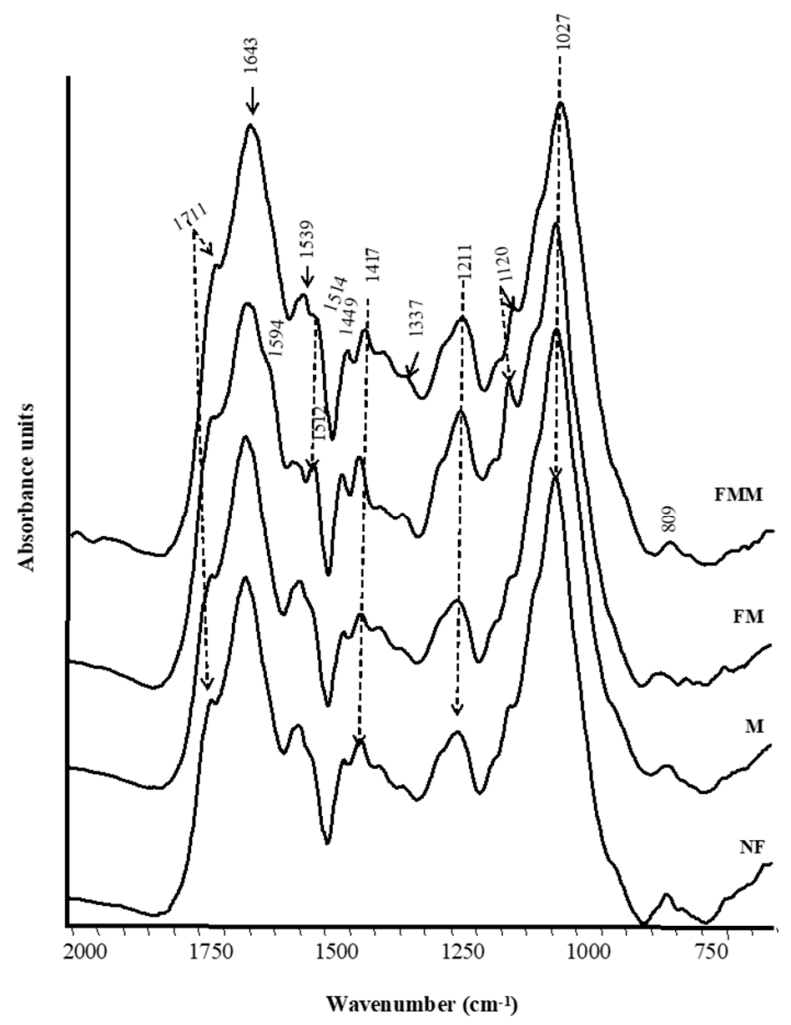

Figure 2. FT-IR spectra of humic substances (HS) extracted from earthworm coprolites collected in soils fertilized with no inputs (NF), or with manure (FM), mineral fertilizers (M) and with manure plus mineral fertilizers (FMM).
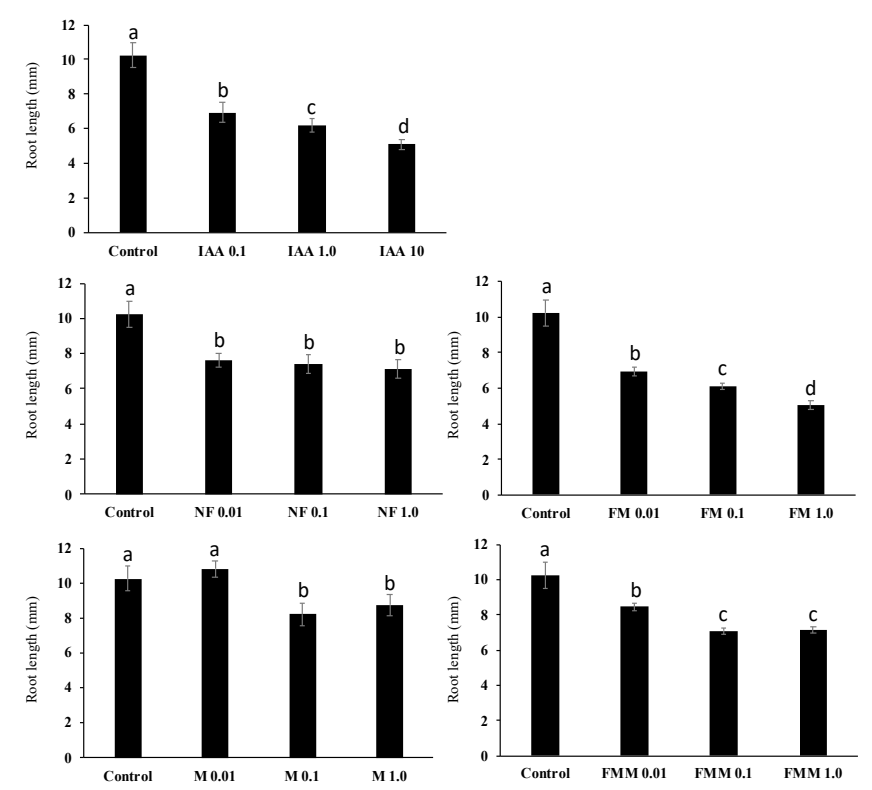

Figure 3. Auxin-like activity of HS from earthworm coprolites collected in soils fertilized with no inputs (NF), manure (FM), mineral fertilizers (M) or manure plus mineral fertilizers (FMM). Data represent the means of three measurements with ten plants in each. Values above bars following the same letter are not statistically different at $p<0.05$ according to Student-Newman-Keuls test. 

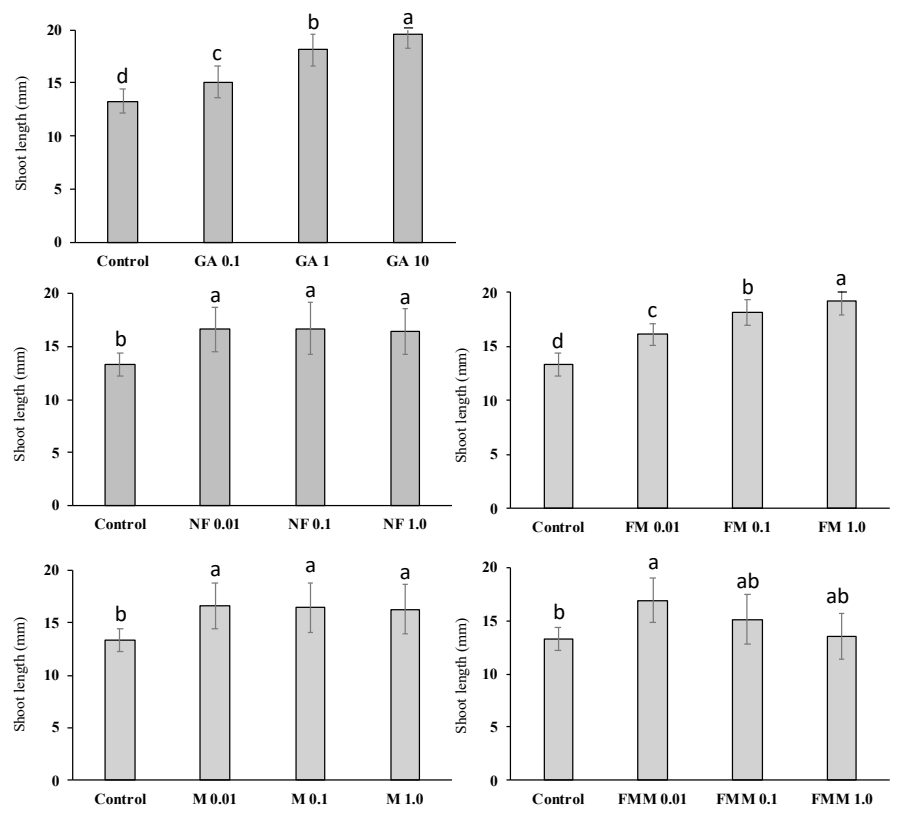

Figure 4. Gibberellin-like activity of HS extracted from earthworm coprolites collected in soils fertilized with no inputs (NF), manure (FM), mineral fertilizers (M) or manure plus mineral fertilizers (FMM). Data represent the means of three measurements with ten plants in each. Values above bars following the same letter are not statistically different at $p<0.05$ according to Student-Newman-Keuls test.

\subsection{Effects of HS on Oat Plant Growth, Chlorophyll and Nutrient Content}

The effects of HS extracted from coprolites on oat plant performance were evaluated in terms of biomass production (Figure 5A) and accumulation of chlorophyll and mineral nutrients (Table 2). When HS of coprolites collected from FM soil were supplied to plants at either $15 \mathrm{mg} \mathrm{C} / \mathrm{L}$ or $25 \mathrm{mg}$ $\mathrm{C} / \mathrm{L}$, the dry weight (DW) of plants was increased by $24 \%$ and $18 \%$, respectively, compared to HS untreated plants (controls). Conversely, HS obtained from coprolites of NF and M soils and applied to plants at either $15 \mathrm{mg} \mathrm{C/L}$ or $25 \mathrm{mg} \mathrm{C} / \mathrm{L}$ did not produce any significant change in plant biomass. HS of coprolites derived from FMM soil determined a plant growth increase ranging from $15 \%$ to $18 \%$ compared to untreated plants.

The trend of chlorophyll a (Chla) and b (Chlb) was as similar as that described for the dry weight, but differences in triggered effects were more remarkable for Chlb, especially when HS of coprolites from FM were furnished to plants, being values about $262 \%$ higher than those measured in the control plants (Figure 5B). The lowest chlorophyll values were detected in plants supplied with HS of coprolites harvested in NF and M soils.

Plants supplied with HS obtained from either FM or FMM contained higher concentrations of macro- (N, P, K, Ca) and micro-nutrients ( $\mathrm{Fe}, \mathrm{Mn}, \mathrm{Zn}$ ) per plant compared to untreated plants and plants supplied with HS of coprolites from NF and M soils. (Table 2). HS extracted from coprolites of FM soil, however, induced the greatest accumulation of nutrients in oat plants, especially when provided at the lower dosage $(15 \mathrm{mg} \mathrm{C} / \mathrm{L})$. 
Table 2. Leaf elemental composition of plants supplied for $48 \mathrm{~h}$ with HS extracted from earthworm coprolites collected in soil plots fertilized with no inputs (NF), manure (FM), mineral fertilizers (M) and with manure plus mineral fertilizers (FMM). Data for N, P, and K are expressed in percent (g/g dry weight), while for other nutrients they were expressed in $\mathrm{mg} / \mathrm{g}$ dry weight. Data represent the means of three measurements with ten plants in each. Values in the same column following the same letter are not statistically different at $p<0.05$ according to Student-Newman-Keuls test.

\begin{tabular}{|c|c|c|c|c|c|c|c|c|c|c|c|c|c|c|}
\hline \multirow{2}{*}{$\begin{array}{c}\text { Treatment } \\
\text { Contr }\end{array}$} & \multicolumn{2}{|c|}{$\underset{\%(g / 100 g \text { d.wt. })}{\mathrm{N}}$} & \multicolumn{2}{|r|}{$\mathbf{P}$} & \multicolumn{2}{|r|}{$\mathbf{K}$} & & \multicolumn{2}{|l|}{$\mathrm{Ca}$} & \multicolumn{2}{|l|}{$\mathrm{Fe}$} & \multicolumn{2}{|l|}{ Mn } & $\mathrm{Zn}$ \\
\hline & 4.71 & $\pm 0.10 \mathrm{~b}$ & 6.60 & $\pm 0.25 b$ & 20.50 & $\pm 1.03 \mathrm{~b}$ & & $\pm 0.13 \mathrm{c}$ & 0.43 & $\pm 0.04 \mathrm{e}$ & 0.061 & $\pm 0.003 \mathrm{~d}$ & 0.19 & $\pm 0.02 \mathrm{~b}$ \\
\hline NF 15 & 5.01 & $\pm 0.10 \mathrm{a}$ & 7.12 & $\pm 0.33 b$ & 21.80 & $\pm 1.12 \mathrm{~b}$ & 1.26 & $\pm 0.10 \mathrm{c}$ & 0.48 & $\pm 0.05 \mathrm{e}$ & 0.077 & $\pm 0.004 \mathrm{~b}$ & 0.22 & $\pm 0.01 \mathrm{ab}$ \\
\hline NF 25 & 5.00 & $\pm 0.10 \mathrm{a}$ & 8.14 & $\pm 0.33 \mathrm{a}$ & 21.39 & $\pm 1.35 \mathrm{~b}$ & 1.25 & $\pm 0.12 \mathrm{c}$ & 0.49 & $\pm 0.03 \mathrm{e}$ & 0.079 & $\pm 0.004 b$ & 0,19 & $\pm 0.02 \mathrm{~b}$ \\
\hline FM 15 & 5.33 & $\pm 0.31 \mathrm{a}$ & 8.12 & $\pm 0.23 \mathrm{a}$ & 26.12 & $\pm 0.85 \mathrm{a}$ & 1.82 & $\pm 0.12 \mathrm{a}$ & 0.88 & $\pm 0.01 \mathrm{a}$ & 0.102 & $\pm 0.001 \mathrm{a}$ & 0.23 & $\pm 0.01 \mathrm{a}$ \\
\hline FM 25 & 5.12 & $\pm 0.15 \mathrm{a}$ & 7.90 & $\pm 0.21 \mathrm{a}$ & 25.33 & $\pm 0.56 \mathrm{a}$ & 1.72 & $\pm 0.12 \mathrm{ab}$ & 0.81 & $\pm 0.01 \mathrm{~b}$ & 0.080 & $\pm 0.001 \mathrm{~b}$ & 0.23 & $\pm 0.03 \mathrm{ab}$ \\
\hline M 15 & 4.63 & $\pm 0.20 \mathrm{~b}$ & 6.95 & $\pm 0.14 \mathrm{~b}$ & 22.95 & $\pm 0.13 b$ & 1.50 & $\pm 0.15 \mathrm{~b}$ & 0.66 & $\pm 0.03 \mathrm{~cd}$ & 0.071 & $\pm 0.005 \mathrm{bc}$ & 0.20 & $\pm 0.01 \mathrm{~b}$ \\
\hline M 25 & 4.50 & $\pm 0.18 \mathrm{~b}$ & 6.71 & $\pm 0.10 \mathrm{~b}$ & 22.61 & $\pm 0.14 \mathrm{~b}$ & 1.40 & $\pm 0.13 \mathrm{~b}$ & 0.63 & $\pm 0.02 \mathrm{~d}$ & 0.063 & $\pm 0.002 \mathrm{~d}$ & 0.19 & $\pm 0.01 \mathrm{~b}$ \\
\hline FMM 15 & 5.02 & $\pm 0.15 \mathrm{a}$ & 7.50 & $\pm 0.35 \mathrm{ab}$ & 24.82 & $\pm 1.03 \mathrm{a}$ & 1.66 & $\pm 0.18 \mathrm{ab}$ & 0.74 & $\pm 0.05 \mathrm{bc}$ & 0.080 & $\pm 0.003 \mathrm{~b}$ & 0.22 & $\pm 0.03 \mathrm{ab}$ \\
\hline FMM 25 & 4.90 & $\pm 0.13 \mathrm{a}$ & 7.31 & $\pm 0.18 \mathrm{~b}$ & 24.24 & $\pm 1.10 \mathrm{ab}$ & 1.53 & $\pm 0.14 \mathrm{ab}$ & 0.70 & $\pm 0.02 \mathrm{c}$ & 0.071 & $\pm 0.003 \mathrm{c}$ & 0.21 & $\pm 0.02 \mathrm{ab}$ \\
\hline
\end{tabular}


A.

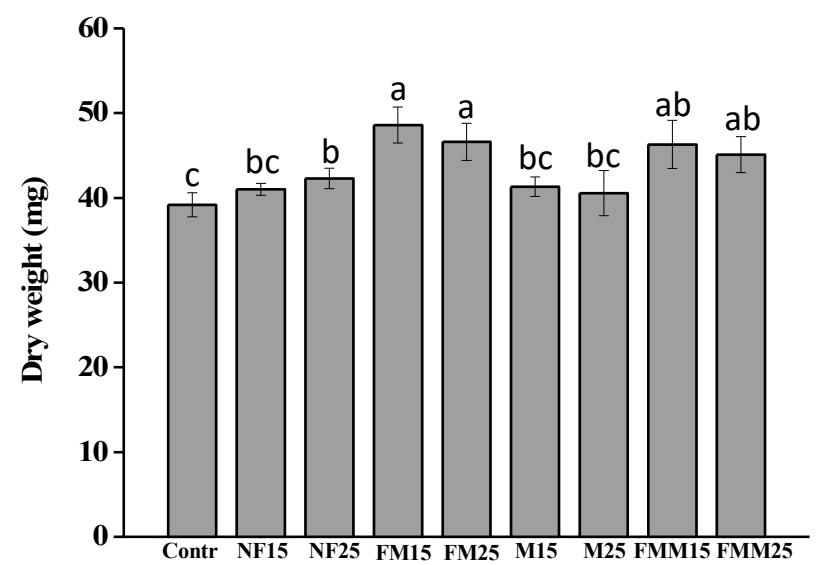

B.

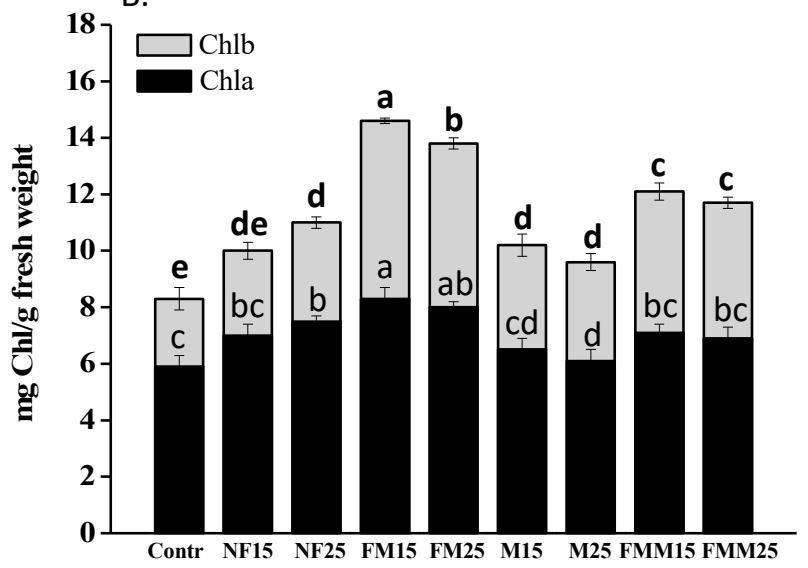

Figure 5. Dry weight (A) and chlorophyll content (B) of oat plant treated with HS extracted from earthworm coprolites collected in soils fertilized with no inputs (NF), or with manure (FM), mineral fertilizers (M) and with manure plus mineral fertilizers (FMM). HS were supplied for two days at two dosages, either $15 \mathrm{mg} \mathrm{C/L}$ or $25 \mathrm{mg} \mathrm{C} / \mathrm{L}$. Control plants (contr) were not added with HS. Data represent the means of three measurements. Values above bars following the same letter are not statistically different at $p<0.05$ according to Student-Newman-Keuls test.

\subsection{Effects of HS on the Activity of N Assimilation Enzymes}

The variation in activity of nitrogen assimilation enzymes, nitrate reductase, and glutamine synthase, was evaluated in oat plants treated with HS of coprolites collected from the soil plots subjected to different fertilization conditions is shown in Figure 6A,B. Changes in activity of NR and GS enzymes in leaves of plants in response to the different HS applied were similar, except for NF. Indeed, the activity of NR in leaves of plants treated with HS of coprolites from non-fertilized soil plot was comparable to that of plants given with HS of coprolites from FM soil (Figure 6A), while GS activity was lower (Figure 6B). NR and GS activity in leaves of plants treated with HS from coprolites of FMM soil displayed the lowest values and similar to those of untreated plants. 

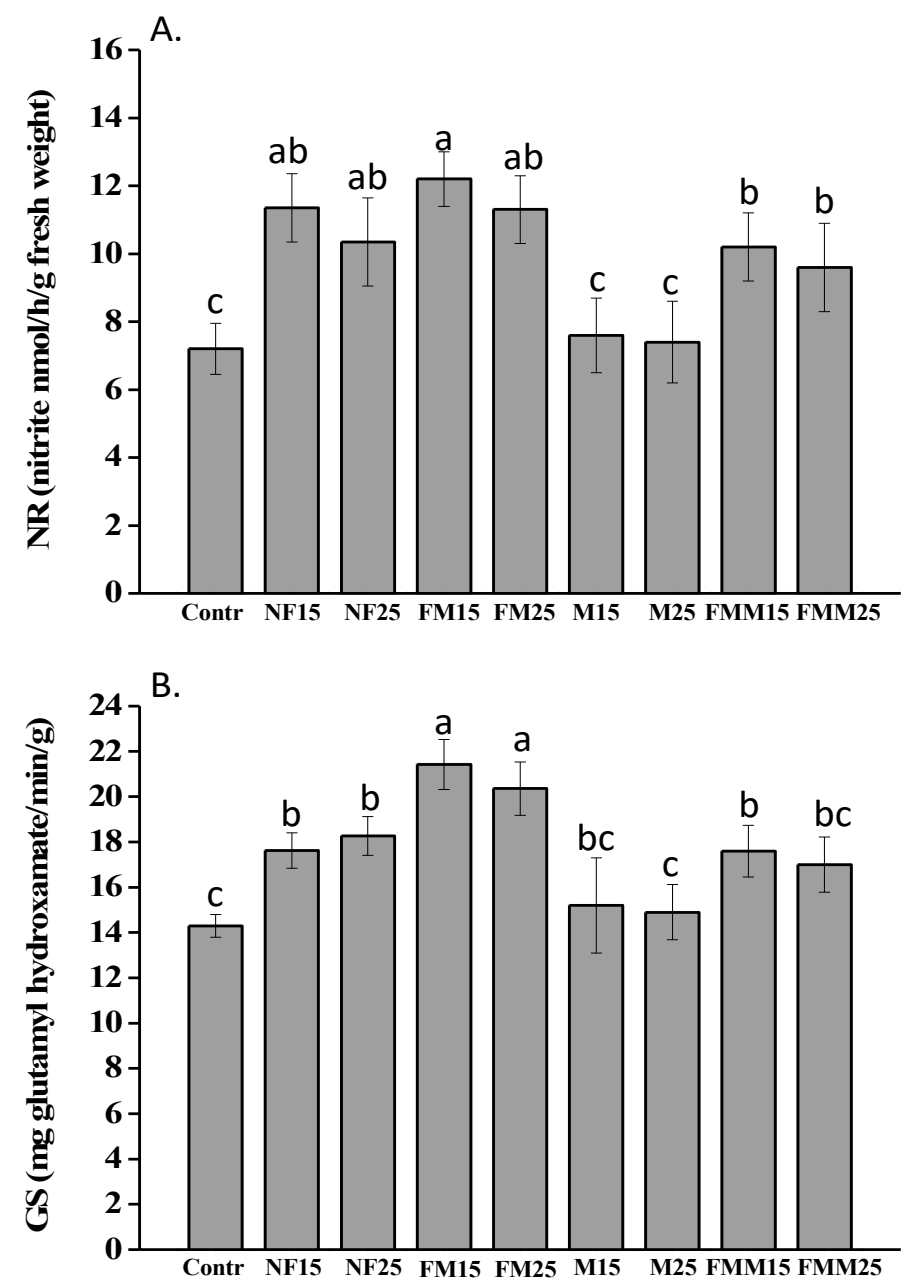

Figure 6. Effect of HS extracted from earthworm coprolites collected in soils fertilized with no inputs (NF), or with manure (FM), mineral fertilizers (M) and with manure plus mineral fertilizers (FMM), on the activity of (A) nitrate reductase (NR) and (B) glutamine synthase (GS) enzymes. HS were supplied for two days at two dosages, either $15 \mathrm{mg} \mathrm{C} / \mathrm{L}$ or $25 \mathrm{mg} \mathrm{C/L}$, to oat plants grown for 12 days in a Hoagland modified nutrient solution. Control plants (contr) were not added with HS. Data represent the means of three measurements with five plants in each (SD). Different letters above bars indicate significant differences between treatments at $p<0.05$ according to Student-Newman-Keuls test.

\section{Discussion}

The widespread use of mineral fertilizers in crop farming has increasingly led to a significant decline of agricultural soil organic matter, which in turn has resulted in soil degradation and negative impacts on environmental ecosystems. In light of these considerations, the adoption of environmental, sustainable, friendly-strategies able to preserve the soil fertility and ensure high crop yields, should be preferred to the soil mineral fertilization. The type of fertilization input is important in determining the earthworm density and population biodiversity in soil, which thus affects the production and quality of earthworm coprolites that influence the soil fertility and crop production. Earthworms and their coprolites are indeed recognized as pivotal biology components of soil [46].

In this study, we first evaluated the effects of different long-term fertilization approaches on the quality of earthworm coprolites and their endogenous HS, and further assayed the biostimulant properties of HS in oat plants grown in soil-less system. Biostimulants include substances in combination or not with microorganisms that promote plant growth, development, and resistance to stress when applied in negligible amounts to crops [16,47]. Previous studies have indicated the existence of a relationship between HS composition and chemical structure, which is then responsible for their 
biological properties and the physiological effects triggered in plants [8]. However, the effects of different fertilization inputs on the quality of HS from earthworm coprolites and their efficiency for a possible use a biofertilizers has been poorly investigated.

Our results show that different fertilization practices could effectively affect the quality of earthworm coprolites, as they displayed different chemical properties, especially with respect to the OC content. Earthworm coprolites collected in soil amended with manure alone (FM) or in combination with mineral fertilizers (FMM) in particular, were the most enriched in OC, thus indicating that mineral fertilization alone did not facilitate the evolution of OM in soil. It is possible that the activity of earthworm was stimulated under organic fertilizer input, while limited by mineral fertilizer application [48]. Also, HS extracted from these coprolites contained the highest amounts of humic carbon (HC). Because OC of earthworm coprolites and HC in their HS can influence soil fertility and crop performance, they could represent better indicators of the soil quality than the $\mathrm{C} / \mathrm{N}$ ratio of earthworm coprolites, which in the current study was not useful in denoting differences in the quality of fertilized soils.

Beside influencing the quantity of humic carbon in HS from earthworm coprolites, the fertilization input had an effect on the molecular complexity and apparent molecular weight distribution of the different HS, as well as in their content of functional groups. The amendment of soil with manure led to an increase in carboxylate and aromatic groups of HS from earthworm coprolites that might be ascribed to a positive impact of manure on the degradation process of plant residues [37]. This hypothesis is supported by the increase of the HS fraction percentage with a high degree of polycondensation (FI), which is usually positively associated with the soil fertility.

The high abundance of carboxylic and aromatic groups in HS from earthworm coprolites picked in soil amended with manure is of biological importance, as in previous studies these groups have been reported to be responsible for eliciting hormone-like (e.g., IAA-like and GA-like) responses in plants $[8,49]$. In this study, we found that these HS were the only to be endowed with both IAA-like and GA-like activities. The IAA-like activity could be ascribed to presence of endogenous IAA and other auxins (e.g., phenylacetic acid and indole butyric acid), all containing a carboxyl group in addition to a hydrophobic ring [50]. Other aromatic groups with biological activity in HS, like phenol-C groups, can also contribute to explain their IAA-like activity, as reported by Muscolo et al. [30] and Pizzeghello et al. [51]. According to these studies, the same or other phenol-C groups can account for the GA-like activity of HS as well.

In order to assay whether HS from earthworm coprolites collected in soil plots subjected to different fertilization practices possessed different capacity to stimulate crop productivity, oat plants were grown in a soil-less system and supplied for two days with HS at two dosages. According to Canellas and Olivares [31], the high molecular humic size is mainly responsible for positive effects on plant metabolism, while Nardi et al. [52] reported that both low molecular and high molecular humic size are effective in this respect. The supply of high molecular size HS extracted from earthworm coprolites deriving from FM and FMM soils determined the highest increases in plant biomass and accumulation of chlorophylls compared to HS untreated plants. Elevated contents of photosynthetic pigments are known to positively correlate with the photosynthetic process in plants, which is responsible for the production of photosynthates contributing to plant growth. Consistently with our findings, higher SPAD (Soil Plant Analysis Development) values, which are indicative of higher chlorophyll content in plants, and enhanced Rubisco activity and sugar production were previously observed in maize plants treated with lignohumates [53]. The same HS from earthworm coprolites of FM and FMM soils also improved plant nutrition. In literature, HS are known to affect nutrient bioavailability by forming complexes with metallic ions, thus improving accessibility of micronutrient and macronutrients [54]. They can additionally favor plant nutrition by stimulating the activity of plasma membrane $\mathrm{H}^{+}$-ATPases, enhance the gene expression and activity of mineral nutrient transporters, and modify the root growth and architecture via hormone-like effects that promote the plant cellular division and elongation processes $[8,14,24,49]$. Recently, the effects of humic acids on root architecture, including the induction 
of lateral roots and the increase of biomass have been reported to be accompanied by changes in the energy metabolism-associated proteins [27].

HS have been additionally reported to stimulate plant growth by targeting pivotal pathways of plant metabolism, primarily nitrogen assimilation [52-54]. The activity of the nitrogen assimilation enzyme GS, was more increased by HS extracted from earthworm coprolites collected in FM, likely because of higher $\mathrm{N}$ uptake and accumulation by plants. NR and GS are enzymes whose increase in activity has been evaluated in several studies as a marker for establishing the biostimulant properties of HS and other products [55-58]. Interestingly, the GS activity strongly correlates $\left(R^{2}=98 \%\right)$ with the amount of chlorophyll pigments, which are N-metabolites. Therefore, HS could influence $\mathrm{N}$ assimilation and photosynthesis mutually. The enhancement of both metabolic processes was likely pivotal in determining promotion of plant growth.

\section{Materials and Methods}

\subsection{Experimental Setup and HS Extraction}

Earthworm coprolites were collected from the soil of the Experimental Farm of Padua University situated in Legnaro (Italy, NE $45^{\circ} 21^{\prime} ; 11^{\circ} 58^{\prime} \mathrm{E} ; 6 \mathrm{~m}$ a.s.l.). This soil has been subjected to a long-term experiment started in 1962, which represents the longest running rotation trial performed in Italy aimed at studying the organic matter turnover and the $C$ stock in long periods. The soil is a fluvi-calcaric cambisol, silty or sandy loam, characterized by a sub-basic $\mathrm{pH}$. Individual plots of this soil experienced different fertilization inputs: (i) fertilization with only organic input (FM $=$ farmyard manure, $60 \mathrm{tha}^{-1} \mathrm{y}^{-1}, 20 \%$ dry matter); (ii) fertilization with only mineral input ( $\mathrm{M}=$ high mineral input,

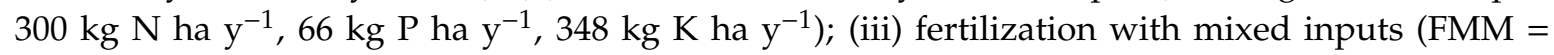
farmyard manure, $30 \mathrm{t} \mathrm{ha}^{-1} \mathrm{y}^{-1}, 20 \%$ dry matter plus mineral input, $150 \mathrm{~kg} \mathrm{~N}$ ha $\mathrm{y}^{-1}, 33 \mathrm{~kg}$ P ha $\mathrm{y}^{-1}$, $174 \mathrm{~kg} \mathrm{~K}$ ha y$^{-1}$ ); (iv) no fertilization (NF) [59,60]. The experimental setup was randomized, with three replicates on $7.8 \mathrm{~m} \times 6 \mathrm{~m}$ plot size. Coprolites of Nicodrilus $(=$ Allolobophora $($ Eisen $)=$ Aporrectodea (Oerley)) caliginosus (Savigny) and Allolobophora rosea (Savigny) were collected from the whole surface of unamended and fertilized soils at the farm and mixed and analyzed together. The two species of earthworms were identified and classified by the expert in the field, Prof. Maurizio Paoletti (personal communication). Once collected, coprolites were air-dried. Their $\mathrm{pH}$ was determined in water with a coprolite to water ratio of 1:2.5.

Humic substances were extracted from $20 \mathrm{~g}$ of coprolites using $0.1 \mathrm{~N} \mathrm{KOH}(200 \mathrm{~mL})$. The extract was dialyzed against distilled water with a $14 \mathrm{kDa}$ molecular weight cut-off Visking membrane (Medicell, UK) according to Nardi et al. [15], desalted with ion exchange Amberlite IR-120 $\left(\mathrm{H}^{+}\right.$ form) [61]. The dialyzed solution $(\mathrm{pH}=3)$ was reduced in volume to about $50 \mathrm{~mL}$, and freeze-dried. From $20 \mathrm{~g}$ of coprolites, $0.76 \mathrm{~g}$ of humic carbon was obtained. Humic carbon content was determined by the Walkley-Black method [62], using the oxidation with $\mathrm{K}_{2} \mathrm{C}_{2} \mathrm{O}_{7} 0.1 \mathrm{M}$.

\subsection{Chemical Analyses and Apparent Molecular Weight Distribution of HS}

The $\mathrm{pH}$ of HS was measured in water (ratio 1:2.5). Organic carbon and nitrogen $(\mathrm{N})$ content in extracts were determined using an element analyzer (vario MACRO CNS, Hanau, Germany). The organic matter value was obtained by multiplying the organic carbon percentage by 1.72 [63]. HS molecular-weight distribution was determined via gel filtration and chromatography [64]. The column calibration was obtained using standard proteins (Kit MS-II, Serva, Heidelberg, Germany). The apparent molecular weight of the various fractions was assigned as follows: FI > 100.000 Da; FII 10.000-100.000 Da; FIII < 10.000.

\subsection{ATR/FT-IR Analysis of HS}

The FT-IR spectra of HS from coprolites were recorded by using an ALPHA FTIR spectrometer (Bruker Optics, Ettlingen, Germany) equipped with an ATR (attenuated total reflectance) sampling 
device containing a diamond crystal. All spectra were collected by co-addition of 100 scans at a resolution of $4 \mathrm{~cm}^{-1}$ in the range $4000-400 \mathrm{~cm}^{-1}$. A background spectrum was recorded using only the diamond crystal prior to collection of each sample spectrum. The spectra were processed using Grams/386 spectroscopic software (Galactic Industries, Salem, NH, USA).

\subsection{Determination of the Hormone-like Activities of HS}

The Audus [45] test was used to establish the hormone-like activity of HS of coprolites. The IAA (indolacetic-acid)-like activity of HS was indeed estimated by measuring the reduction of watercress (Lepidium sativum L.) root length after treatment with either IAA or HS. Conversely, the gibberellin-like (GA-like) activity was determined by evaluating increases in length of lettuce (Lactuca sativa L.) epicotyls following application of GA and HS [45]. For each HS, the initial dosage applied was $1 \mathrm{~mL}$ (1.0), which was further subjected to $10 \times(0.1)$ and $100 \times(0.01)$ dilutions according to Ertani et al. [65]. Specifically, watercress and lettuce seeds were surface-sterilized through soaking in $8 \%(\mathrm{v} / \mathrm{v})$ hydrogen peroxide for $15 \mathrm{~min}$. After rinsing five times with sterile distilled water, seeds were placed on sterile filter papers inside sterile Petri dishes (10 seeds per dish). For watercress, the filter paper was wetted with $1.2 \mathrm{~mL}$ of $1 \mathrm{mM} \mathrm{CaSO}_{4}$ (control), or $1.2 \mathrm{~mL}$ of $0.1,1,10,20 \mathrm{mg} \mathrm{L}^{-1}$ IAA solution (Sigma, Milan, Italy) for the calibration curve, or $1.2 \mathrm{~mL}$ of a serial dilution of HS. For lettuce, the experimental design was the same as described for watercress except that the sterile filter paper was wetted with $1.4 \mathrm{~mL}$ instead of $1.2 \mathrm{~mL}$, and the calibration curve was a progression of $0.1,1,10,100 \mathrm{mg} \mathrm{L}^{-1} \mathrm{GA}$ solution (Sigma, Milan, Italy). The seeds were held in a germination room in the dark at $25^{\circ} \mathrm{C}$. After $48 \mathrm{~h}$ for watercress and $72 \mathrm{~h}$ for lettuce, seedlings were removed and the root or epicotyl lengths were measured with a TESA-CAL IP67 electronic calibre (TESA, Renens, Switzerland) and Data Direct software, version 1 (ArtWare, Asti, Italy). The values obtained were the means of 20 samples and five replications, with the standard errors always lower than $5 \%$ of the mean.

\subsection{Plant Growth Conditions}

Oat seeds (Avena Sativa var. Goodfield) were sterilized using $0.1 \mathrm{M} \mathrm{Na}(\mathrm{ClO})[66]$ and sowed in pots (density $=16$ seeds per pot) filled with sand and placed inside a climatic chamber with a $12 \mathrm{~h}$ light $/ 12 \mathrm{~h}$ dark cycle, air temperature of $24 / 21{ }^{\circ} \mathrm{C}$, relative humidity of $70 / 85 \%$. The seeds were allowed to germinate in the pots for one week in the presence of water. After this period, germinated seedlings were selected for homogeneity and only 10 per pot were left. To each pot, a Hoagland modified nutrient solution $(100 \mathrm{~mL})$ was added every 2 days. The nutrient solution had the following composition ( $\mu \mathrm{mol} / \mathrm{L}$ ): $\mathrm{Ca}\left(\mathrm{NO}_{3}\right)_{2}(200), \mathrm{KNO}_{3}(200), \mathrm{MgSO}_{4}(200), \mathrm{KH}_{2} \mathrm{PO}_{4}$ (40), FeNaEDTA (10), $\mathrm{H}_{3} \mathrm{BO}_{3}$ (4.6), $\mathrm{MnCl}_{2}$ (0.9), $\mathrm{ZnCl}_{2}$ (0.09), $\mathrm{CuCl}_{2}(0.036), \mathrm{NaMoO}_{4}$ (0.01). At the fifth day, HS were also supplied in a unique application to plants for $48 \mathrm{~h}$ by addition to the nutrient solution, and the dosages applied corresponded to 15 and $25 \mathrm{mg}$ C/L. These dosages were selected based on preliminary experiments. Plants that were not treated with HS served as controls. For each experimental condition, five pots were prepared. The experiment was repeated three times and was performed according to a randomized block design. After 14 days from sowing, plants were randomly harvested, roots were carefully washed to remove sand particles and dried with blotting paper. A sub-sample of the plant material was immediately frozen with liquid nitrogen and kept at $-80^{\circ} \mathrm{C}$ for physiological analyses. For fresh and dry weight measurement, ten plants per individual treatment collected from different pots were used. After measuring the fresh weight, leaf samples of individual plants were placed in a drying oven for 2 days at $70{ }^{\circ} \mathrm{C}$, allowed to cool for $2 \mathrm{~h}$ inside a closed bell jar and weighed separately.

\subsection{Quantification of Chlorophyll Content and Mineral Nutrients}

For the determination of chlorophyll content, fresh foliar tissue $(150 \mathrm{mg})$ was ground in liquid nitrogen and extracted with $15 \mathrm{~mL}$ of ethanol $(96 \% \mathrm{v} / \mathrm{v})$. The samples were kept in the dark for 2 days at $4{ }^{\circ} \mathrm{C}$, and the extracts were filtered and then analysed spectrophotometrically (UV/vis Lambda 1; PerkinElmer, Norwalk, CT) at $\lambda=665 \mathrm{~nm}$ for chlorophyll a (Chla) and $649 \mathrm{~nm}$ for chlorophyll $\mathrm{b}$ (Chlb). 
The concentration of Chla and Chlb in each sample was calculated using the Welburn and Lichtenthaler formula [67]. Two measurements were performed for each plant, using six plants per treatment.

The determination of mineral nutrients in leaves of oat plants was performed after an acid-digestion procedure. Digestion reactions were carried out inside closed Teflon vessels of $100 \mathrm{~mL}$ volume using $500 \mathrm{mg}$ dry plant material in $9 \mathrm{~mL} \mathrm{HNO}_{3}$ and $\mathrm{H}_{2} \mathrm{O}_{2} 30 \%$ (7:2) in a microwave (Millestone Start-D 1200W). Mineralized samples were then diluted in $25 \mathrm{~mL}$ ultrapure water and each element was assayed via Inductively Coupled Plasma Atomic Emission Spectroscopy (Optima 2000 DV, Perkin Elmer Instruments Germany).

\subsection{Enzyme Extraction and Assay Conditions}

For the extraction of nitrate reductase (NR, E.C.1.7.1.1) and glutamine synthetase (GS, EC 6.3.1.2), leaf tissues $(1 \mathrm{~g})$ were ground in a mortar and added with $100 \mathrm{mM}$ HEPES (acido 4-2-idrossietil-1-piperazinil-etansolfonico)- $\mathrm{NaOH}$ pH 7.5, $5 \mathrm{mM} \mathrm{MgCl}$, and $1 \mathrm{mM}$ dithiothreitol (DTT). The ratio of plant material to mixture solution was 1:3 (v/v). Extracts were filtered through two layers of muslin and clarified by centrifugation at $20,000 \mathrm{~g} \times 15 \mathrm{~min}$. The supernatant was then used for the enzymatic assay. All steps were carefully performed at $4{ }^{\circ} \mathrm{C}$ [56]. The activity of nitrate reductase (NR) was determined in a solution containing $100 \mathrm{mM} \mathrm{KH}_{2} \mathrm{PO}_{4}, 100 \mathrm{mM} \mathrm{KNO}_{3}$, and $400 \mu \mathrm{L}$ of enzyme extract. The activity was measured spectrophotometrically at $\lambda=540 \mathrm{~nm}$, and the calibration curve was plotted against known concentrations of $\mathrm{NaNO}_{2}$ [68]. For glutamine synthetase (GS, EC 6.3.1.2) assay, the mixture contained $90 \mathrm{mM}$ imidazole- $\mathrm{HCl}$ (pH 7.0), $60 \mathrm{mM}$ hydroxylamine (neutralized), $20 \mathrm{mM} \mathrm{KAsO}_{4}, 3 \mathrm{mM} \mathrm{MnCl}_{2}, 0.4 \mathrm{mM} \mathrm{ADP}, 120 \mathrm{mM}$ glutamine, and the appropriate amount of enzyme extract. The assay was performed in a final volume of $750 \mu \mathrm{L}$. The enzymatic reaction was developed colorimetrically for $15 \mathrm{~min}$ at $37^{\circ} \mathrm{C}$. The $\gamma$-glutamyl hydroxamate was calorimetrically determined by the addition of $250 \mu \mathrm{L}$ of a mixture (1:1:1) of $10 \%(\mathrm{w} / \mathrm{v}) \mathrm{FeCl} 3 \cdot 6 \mathrm{H} 2 \mathrm{O}$ in $0.2 \mathrm{M} \mathrm{HCl}, 24 \%(\mathrm{w} / \mathrm{v})$ trichloroacetic acid, and 50\% (w/v) $\mathrm{HCl}$. The optical density was recorded at $\lambda=540 \mathrm{~nm}$.

\subsection{Statistical Analysis}

For all determinations. the analysis of variance (ANOVA) was performed using the SPSS software version 19.0 (SPSS Inc. 1999), and was followed by pair-wise post hoc analyses (Student-Newman-Keuls test) to determine which means differed significantly at $p<0.05( \pm \mathrm{SD})$. Homogeneity of variances was confirmed by the Levene test (SPSS). The number of biological replicates varied depending on the analysis performed and is indicated in the figures' and tables' legends.

\section{Conclusions}

The results of this study indicate that differences in apparent molecular weight, chemical and structural properties between HS from earthworm coprolites of different soils accounted for differential effects on plant biomass, activity of marker enzymes, and accumulation of photosynthetic pigments and several nutrients. The hormone-like activity of HS from coprolites of earthworms harvested in the soil amended with manure likely was responsible for these effects on the plant physiology. We conclude that the distribution of manure on soil directed the turnover of OM towards the humification process that led to the production of high-quality coprolites and endogenous HS with superior biological activity. Furthermore, we suggest that values of OC in coprolites and HC in HS from earthworm coprolites might be used as reliable indicators of soil fertility.

Author Contributions: Conceptualization: S.N. Methodology and investigation: A.E. and O.F. Formal analysis and data curation: M.S. Writing-Original Draft Preparation: M.S. and S.N. Writing-Review \& Editing: A.E., O.F., M.S., S.N. Funding Acquisition: S.N. All the authors approved the final version of the manuscript.

Funding: This research was funded by DOR2018 provided by University of Padova.

Acknowledgments: We would like to thanks Antonio Berti and Francesco Morari for kindly give us the possibility to collect earthworm material in the Farm of Padova University in Legnaro. This work was realized thank to DOR 2017 funds provided by Padova University. 
Conflicts of Interest: The authors declare no conflict of interest.

\section{References}

1. Baker, G.H.; Brown, G.; Butt, K.; Curry, J.P.; Scullion, J. Introduced earth-worms in agricultural and reclaimed land: Their ecology and influences on soil properties, plant production and other soil biota. Biol. Invasions 2006, 8, 1301-1316. [CrossRef]

2. Atiyeh, R.M.; Lee, S.; Edwards, C.A.; Arancon, N.Q.; Metzger, J.D. The in-fluence of humic acids derived from earthworm-processed organic wastes on plant growth. Bioresour. Technol. 2002, 84, 7-14. [CrossRef]

3. Choosai, C.; Jouquet, P.; Hanboonsong, Y.; Hartmann, C. Effects of earthworms on soil properties and rice production in the rainfed paddy fields of Northeast Thailand. Appl. Soil Ecol. 2010, 45, 298-303. [CrossRef]

4. Van Groenigen, J.W.; Lubbers, I.M.; Vos, H.M.J.; Brown, G.G.; De Deyn, G.B.; van Groenigen, K.J. Earthworms increase plant production: A meta-analysis. Sci. Rep. 2014, 4, 6365. [CrossRef] [PubMed]

5. Kahsnitz, H.G. Investigations on the influence of earthworms on soil and plant. Bot. Arch. 1992, 1, 315-331.

6. Gilot, C. Effects of a tropical geophagous earthworm, M. anomala (Megascolecidae), on soil characteristics and production of a yam crop in Cote d'Ivoire. Soil Biol. Biochem. 1997, 29, 353-359. [CrossRef]

7. Muscolo, A.; Bovalo, F.; Gionfriddo, F.; Nardi, S. Earthworm humic matter produces auxin-like effects on Daucus carota cell growth and nitrate metabolism. Soil Biol. Biochem. 1999, 31, 1303-1311. [CrossRef]

8. Muscolo, A.; Sidari, M.; Nardi, S. Humic substance: Relationship between structure and activity. Deeper information suggests univocal findings. J. Geochem. Explor. 2013, 129, 57-63. [CrossRef]

9. Vaccaro, S.; Muscolo, A.; Pizzeghello, D.; Spaccini, R.; Piccolo, A.; Nardi, S. Effect of a compost and its water-soluble fractions on key enzymes of nitrogen metabolism in maize seedlings. J. Agric. Food Chem. 2009, 57, 11267-11276. [CrossRef]

10. Calderín García, A.; Huertas Tavares, O.; Martínez Balmori, D.; dos Santos Almeida, V.; Pasqualoto Canellas, L.; García-Mina, J.M.; Berbara1, L.L. Structure-function relationship of vermicompost humic fractions for use in agriculture. J. Soil Sediment 2018, 18, 1365-1375. [CrossRef]

11. Darwin, C. The formation of vegetable mold through the action of worms, with observations of their habits. In The Essential Darwin; Ridley, M., Ed.; Allen and Unwin: London, UK, 1881; pp. 237-256.

12. Evans, A.C. The importance of earthworms. Farming 1948, 2, 59-60.

13. Muscolo, A.; Cutrupi, S.; Nardi, S. IAA detection in humic matter. Soil Biol. Biochem. 1998, 30, $1199-1201$. [CrossRef]

14. Canellas, L.P.; Olivares, F.L.; Okorokova-Facanha, A.L.; Façanha, A.R. Humic acids isolated from earthworm compost enhance root elongation, lateral root emergence, and plasma membrane H-ATPase activity in maize roots. Plant Physiol. 2002, 130, 1951-1957. [CrossRef] [PubMed]

15. Nardi, S.; Morari, F.; Berti, A.; Tosoni, M.; Giardini, L. Soil organic matter properties after 40 years of different use of organic and mineral fertilisers. Eur. J. Agron. 2004, 21, 357-367. [CrossRef]

16. Nardi, S.; Pizzeghello, D.; Schiavon, M.; Ertani, A. Plant biostimulants: Physiological responses induced by protein hydrolyzed-based products and humic substances in plant metabolism. Sci. Agric. 2016, 73, 18-23. [CrossRef]

17. Piccolo, A. The supramolecular structure of humic substances. Soil Sci. 2001, 166, 810-832. [CrossRef]

18. Sutton, R.; Sposito, G. Molecular structure in soil humic substances: The new view. Environ. Sci. Technol. 2005, 39, 9009-9015. [CrossRef]

19. Swift, R.S. Macromolecular properties of soil humic substances: Fact, fiction and opinion. Soil Sci. 1999, 164, 790-802. [CrossRef]

20. Clapp, C.E.; Hayes, M.H.B. Sizes and shapes of humic substances. Soil Sci. 1999, 164, 777-789. [CrossRef]

21. Wershaw, R.L. Molecular aggregation of humic substances. Soil Sci. 1999, 164, 803-813. [CrossRef]

22. Lehmann, J.; Kleber, M. The contentious nature of soil organic matter. Nature 2015, 528, 61-68. [CrossRef] [PubMed]

23. Gerke, J. Concepts and misconceptions of humic substances as the stable part of soil organic matter: A review. Agronomy 2018, 8, 76. [CrossRef]

24. Shah, Z.H.; Rehman, H.M.; Akhtar, T.; Alsamadany, H.; Hamooh, B.T.; Mujtaba, T.; Daur, I.; Al Zahrani, Y.; Alzahrani, H.A.S.; Ali, S.; et al. Humic Substances: Determining Potential Molecular Regulatory Processes in Plants. Front. Plant Sci. 2018, 9, 263. [CrossRef] [PubMed] 
25. Schiavon, M.; Pizzeghello, D.; Muscolo, A.; Nardi, S. High molecular size humic substances enhance phenylpropanoid metabolism in maize (Zea mays L.). J. Chem. Ecol. 2010, 36, 662-669. [CrossRef]

26. Canellas, L.P.; Olivares, F.L. Physiological responses to humic substances as plant growth promoter. Chem. Biol. Technol. Agric. 2014, 1, 3. [CrossRef]

27. Zandonadi, D.B.; Santos, M.P.; Caixeta, L.S.; Marinho, E.B.; Peres, L.E.P.; Façanha, A.R. Plant proton pumps as markers of biostimulant action. Sci. Hort. 2016, 73, 24-28. [CrossRef]

28. Nardi, S.; Ertani, A.; Francioso, O. Soil-root cross-talking: The role of humic substances. J. Plant Nutr. Soil Sci. 2017, 180, 5-13. [CrossRef]

29. Nunes, R.O.; Domiciano, G.A.; Alves, W.S.; Melo, A.C.A.; Nogueira, F.C.S.; Canellas, L.P.; Olivares, F.L.; Zingali, R.B.; Soares, M.R. Evaluation of the effects of humic acids on maize root architecture by label-free proteomics analysis. Sci Rep. 2019, 9, 12019. [CrossRef]

30. Muscolo, A.; Sidari, M.; Attinà, E.; Francioso, O.; Tugnoli, V.; Nardi, S. Biological activity of humic substances is related to their chemical structure. Soil Sci. Soc. Am. J. 2007, 71, 75-85. [CrossRef]

31. Canellas, L.P.; Spaccini, R.; Piccolo, A.; Dobbss, L.B.; Okorokova-Façanha, A.L.; Santos, G.A.; Olivares, F.L.; Façanha, A.R. Relationships between chemical characteristics and root growth promotion of humic acids isolated from Brazilian Oxisols. Soil Sci. 2009, 174, 611-620. [CrossRef]

32. Chan, P.L.S.; Griffiths, D.A. The vermicomposting of pre-treated pig manure. Biol. Wastes 2001, $24,57-69$. [CrossRef]

33. Xiang, C.; Zhang, P.; Pan, G. Changes in diversity, protein content, and amino acid composition of earthworms from a paddy soil under different long-term fertilizations in the Tai Lake Region. Acta Ecologica Sinica 2006, 26, 1667-1673. [CrossRef]

34. Eriksen-Hamel, N.S.; Whalen, J.K. Growth rates of Aporrectodea caliginosa (Oligochaetae: Lumbricidae) as influenced by soil temperature and moisture in disturbed and undisturbed soil columns. Pedobiologia 2006, 50, 207-215. [CrossRef]

35. Eriksen-Hamel, N.S.; Speratti, A.B.; Whalen, J.K.; Légère, A.; Madramootoo, C.A. Earthworm populations and growth rates related to long-term crop residue and tillage management. Soil Tillage Res. 2008, 104, 311-316. [CrossRef]

36. Fonte, S.J.; Winsome, T.; Six, J. Earthworm populations in relation to soil organic matter dynamics and management in California tomato cropping systems. Appl. Soil Ecol. 2009, 41, 206-214. [CrossRef]

37. Simonsen, J.; Posner, J.; Rosemeyer, M.; Baldock, J. Endogeic and anecic earthworm abundance in six Midwestern cropping systems. Appl. Soil Ecol. 2010, 44, 147-155. [CrossRef]

38. Zanin, L.; Tomasi, N.; Cesco, S.; Varanini, Z.; Pinton, R. Humic substances contribute to plant iron nutrition acting as chelators and biostimulants. Front. Plant Sci. 2019, 10, 675. [CrossRef]

39. Ferrari, E.; Francioso, O.; Nardi, S.; Saladini, M.; Dal Ferro, N.; Morari, F. DRIFT and HR MAS NMR characterization of humic substances from a soil treated with different organic and mineral fertilizers. J. Mol. Struct. 2011, 998, 216-224. [CrossRef]

40. Tinti, A.; Tugnoli, V.; Bonora, S.; Francioso, O. Recent applications of vibrational mid-Infrared (IR) spectroscopy for studying soil components: A review. J. Centr. Eur. Agric. 2015, 16, 1-22. [CrossRef]

41. Carletti, P.; Roldan, M.L.; Francioso, O.; Nardi, S.; Sanchez-Cortes, S. Structural characterization of humic-like substances with conventional and surface-enhanced spectroscopic techniques. J. Mol. Struct. 2010, 982, 169-175. [CrossRef]

42. Brunow, G. Lignin, Humic Substances and Coal; Hofrichter, M., Steinbüchel, A., Eds.; Wiley-VCH: Weinheim, Germany, 2001; p. 89.

43. Osono, T.; Takeda, H. Effects of organic chemical quality and mineral nitrogen addition on decomposition of beech leaf litter by Xylaria sp. Eur. J. Soil Biol. 2001, 37, 17-23. [CrossRef]

44. Thevenot, M.; Dignac, M.F.; Rumpel, C. Fate of lignins in soils: A review. Soil Biol. Biochem. 2010, 42, 1200-1211. [CrossRef]

45. Audus, L.J. Plant Growth Substances Chemistry and Physiology; L. Hill: London, UK, 1972; Volume 1, pp. $24-65$.

46. Lemtiri, A.; Colinet, G.; Alabi, T.; Cluzeau, D.; Zirbes, L.; Haubruge, E.; Francis, F. Impacts of earthworms on soil components and dynamics. Biotechnol. Agron. Soc. Environ. 2014, 18, 121-133.

47. Colla, G.; Nardi, S.; Cardarelli, M.; Ertani, A.; Lucini, L.; Canaguier, R.; Rouphael, Y. Protein hydrolysates as biostimulants in horticulture. Sci. Hortic. 2015, 196, 28-38. [CrossRef] 
48. Edwards, C.A.; Lofty, J.R. The effects of direct drilling and minimal cultivation on earthworm populations. J. Appl. Ecol. 1982, 19, 723-734. [CrossRef]

49. Nardi, S.; Concheri, G.; Dell'Agnola, G. Biological activity of humus. In Humic Substances in Terrestrial Ecosystems; Piccolo, A., Ed.; Elsevier: Amsterdam, The Netherlands, 1996; pp. 361-406.

50. Russell, L.; Stokes, A.R.; Macdonald, H.; Muscolo, A.; Nardi, S. Stomatal responses to humic substances and auxin are sensitive to inhibitors of phospholipase A2. Plant Soil 2006, 283, 175-185. [CrossRef]

51. Pizzeghello, D.; Zanella, A.; Carletti, P.; Nardi, S. Chemical and biochemical characterization of dissolved organic matter from Silver fir and beech forest soils. Chemosphere 2006, 65, 190-200. [CrossRef]

52. Nardi, S.; Muscolo, A.; Vaccaro, S.; Baiano, S.; Spaccini, R.; Piccolo, A. Relationship between molecular characteristics of soil humic fractions and glycolytic pathway and krebs cycle in maize seedlings. Soil Biol. Biochem. 2007, 39, 3138-3146. [CrossRef]

53. Ertani, A.; Nardi, S.; Francioso, O.; Pizzeghello, D.; Tinti, A.; Schiavon, M. Metabolite targeted analysis and physiological traits of Zea mays L. In response to application of a leonardite-humate and lignosulfonate-based products for their evaluation as potential biostimulants. Agronomy 2019, 9, 445. [CrossRef]

54. García, A.C.; de Souza, L.G.; Pereira, M.G.; Castro, R.N.; García-Mina, J.M.; Zonta, E.; Lisboa, F.J.; Berbara, R.L. Structure-property-function relationship in humic substances to explain the biological activity in plants. Sci. Rep. 2016, 6, 20798. [CrossRef]

55. Ertani, A.; Francioso, O.; Tugnoli, V.; Righi, V.; Nardi, S. Effect of commercial lignosulfonate-humates on Zea mays L. metabolism. J. Agric. Food Chem. 2011, 59, 11940-11948. [CrossRef] [PubMed]

56. Palumbo, G.; Schiavon, M.; Nardi, S.; Ertani, A.; Celano, G.; Colombo, C.M. Biostimulant potential of humic acids extracted from an amendment obtained via combination of olive mill wastewaters (OMW) and a pre-treated organic material derived from municipal solid waste (MSW). Front. Plant Sci. 2018, 9, 1028. [CrossRef] [PubMed]

57. Schiavon, M.; Ertani, A.; Nardi, S. Effects of an alfalfa protein hydrolysate on the gene expression and activity of enzymes of the tricarboxylic acid (TCA) cycle and nitrogen metabolism in Zea mays L. J. Agric. Food Chem. 2008, 56, 11800-11808. [CrossRef] [PubMed]

58. Baglieri, A.; Cadili, V.; Monterumici, C.M.; Gennaria, M.; Tabasso, S.; Montoneri, R.; Nardi, S.; Negre, M. Fertilization of bean plants with tomato plants hydrolysates. Effect on biomass production, chlorophyll content and N assimilation. Sci. Hort. 2014, 176, 194-199. [CrossRef]

59. Giardini, L.; Giovanardi, R.; Borin, M. Confronto tra quattro rotazioni colturali eseguite per un dodicennio a diversi livelli di concimazione e di irrigazione: Aspetti agronomici ed economici. Rivista di Agronomia 1987, $21,18-27$.

60. Giardini, L.; Borin, M.; Berti, A. Effetti del letame e del liquame bovino in avvicendamenti colturali a diverso livello di concimazione. Rivista di Agronomia 1999, 33, 118-129.

61. Stevenson, F.J. Humus Chemistry: Genesis, Composition, Reactions, 2nd ed.; John Wiley \& Sons: New York, NY, USA, 1994; p. 496.

62. Walkley, A.; Black, I.A. An examination of the Degtjareff method for determining soil organic matter and a proposed modification of the chromic acid titration method. Soil Sci. 1934, 37, 29-38. [CrossRef]

63. Nelson, D.W.; Sommers, L.E. Total carbon, organic carbon, and organic matter. In Methods of Soil Analysis, Part 3; SSSA Book Series No. 5; Madison, WI, USA, 1996; pp. 961-1010. Available online: http://www. scirp.org/(S(351jmbntvnsjt1aadkposzje))/reference/ReferencesPapers.aspx?ReferenceID=2017439 (accessed on 17 October 2019).

64. Dell'Agnola, G.; Ferrari, G. Effect of humic acids on anion uptake by excised barley roots. Humus. Planta 1971, 5, 567-569.

65. Ertani, A.; Cavani, L.; Pizzeghello, D.; Brandellero, E.; Altissimo, A.; Ciavatta, C.; Nardi, S. Biostimulant activity of two protein hydrolysates in the growth and nitrogen metabolism of maize seedlings. J. Plant Nutr. Soil Sci. 2009, 172, 237-244. [CrossRef]

66. Dall'Acqua, S.; Ertani, A.; Pilon-Smits, E.A.H.; Fabrega-Prats, M.; Schiavon, M. Selenium biofortification differentially affects sulfur metabolism and accumulation of phytochemicals in two rocket species (Eruca sativa mill. and Diplotaxis tenuifolia) grown in hydroponics. Plants 2019, 8, 68. [CrossRef] 
67. Welburn, A.R.; Lichtenthaler, H. Formulae and program to determine total carotenoids and chlorophylls A and B of leaf extracts in different solvents. In Advances in Photosynthesis Research. Advances in Agricultural Biotechnology; Sybesma, C., Ed.; Springer: Dordrecht, The Netherlands, 1984; Volume 2.

68. Lewis, O.A.M.; Watson, E.F.; Hewitt, E.J. Determination of nitrate reductase activity in barley leaves and roots. Ann. Bot. 1982, 49, 31-37. [CrossRef]

(C) 2019 by the authors. Licensee MDPI, Basel, Switzerland. This article is an open access article distributed under the terms and conditions of the Creative Commons Attribution (CC BY) license (http://creativecommons.org/licenses/by/4.0/). 